CSILLA BÍRÓ

\title{
ELEMENTS OF LATE STOIC PHILOSOPHY IN GYÖRGY RAJCSÁNYI'S SPIRITUAL WORK LAURUS TUTA
}

Summary: The spiritual work of György Rajcsányi (1670-1734), the Jesuit teacher and moral philosopher of the Jesuit College of Nagyszombat (today Trnava, Slovakia), the Laurus tuta a fulmine seu consignatio sui in providentiam Dei, ex principiis philosophiae sanctioris potissimum desumpta (Nagyszombat 1707 and 1765) pertains to baroque Neostoic philosophy. The beginning of the eighteenth century, the so called "Indian Summer of Hungarian Stoicism" is defined by the publication of several stoical-minded works by a small group of Jesuits (János Rajcsányi, Gábor Kapi, Gergely Berzeviczi, Gergely Hidi, György Rajcsányi) acting in collaboration with the University of Nagyszombat.

György Rajcsányi professedly follows the philosophical writing of Seneca, he even refers to the first chapter of the De providentia where it talks about the natural phenomena created by God. He also cites another work of Seneca, the De vita beata, and the command found in this work, namely Deum sequere!, appears several times throughout the dissertation. The other stoic source he uses is the Handbook of Epictetus that he cites several times, too. Among the sources of the Laurus tuta there is the spiritual work of the Jesuit Alphons Antonio de Sarasa (1618-1667), working in Antwerp and Brussels. His writing, the Ars semper gaudendi, was highly popular and has been published several times, including one publication in Nagyszombat in 1676.

Key words: Divine Providence, Epictetus, Jesuits of Nagyszombat, Neostoicism, György Rajcsányi, Alphons Antonio de Sarasa, Seneca, spirituality of Jesuits

A part of the work of György Rajcsányi (1670-1734), the Jesuit teacher and moral philosopher, namely the edition of Petrarca's "Book of Fortune" has been already analysed by Réka Lengyel, Ágnes Máté and myself. ${ }^{1}$ Still, other religious writings of

\footnotetext{
* This paper was supported by the János Bolyai Research Scholarship of the Hungarian Academy of Sciences.

${ }^{1}$ LENGYel, R.: La fortuna ungherese del Libro di Fortuna del Petrarca (Le edizioni ungheresi del De remediis utriusque fortunae nel secolo 18). Camoenae Hungaricae 3 (2006) 169-174; MÁTÉ Á.: Francesco Petrarca De remediis utriusque Fortunae címủ mủvének 18. századi magyar változatai [Hungarian versions of Francesco Petrarca's De remediis utriusque Fortunae from the 18th century]. In SzÖRÉNYI L. LÁZÁR I. D. (ed.): Varietas gentium, communis latinitas. A XIII. Neolatin Világkongresszus (2006) szegedi
} 
the same author have to be investigated to get a better picture of his educational achievements and spirituality, and also for widening our knowledge about the Jesuit College of Nagyszombat (today Trnava, Slovakia).

György Rajcsányi was the brother of another Jesuit writer, János Rajcsányi (1669-1733). He joined the holy order of the Jesuits in 1687 and followed his education in Vienna and Graz. During his life he also spent time in Nagyszombat, Sopron (Hungary), Rome, Sárospatak (Hungary), Kassa (today Košice, Slovakia) and Kolozsvár (today Cluj-Napoca, Romania). ${ }^{2}$ His career as a writer resulted in the following writings:

- Harmonia philosophica cantus laetiores tristioribus, et tristiores laetioribus attemperans, sive principia quaedam verae ac genuinae philosophiae, animum humanum regulantia, ne vel prosperis evanescat, vel adversis frangatur, ex libris duobus Francisci Petrarchae de remediis utriusque fortunae desumpta. Tyrnaviae, Typis Academicis 1706 - RMK II 2269. ${ }^{3}$

- Ars recte philosophandi seu vitam ex praescripto rationis moderandi desumpta potissimum ex dialogis Francisci Petrarchae de remediis utriusque fortunae. Tyrnaviae, Typis Academicis 1707 - RMK II 2298.

- Laurus tuta a fulmine seu consignatio sui in providentiam Dei. Tyrnaviae, Typis Collegii Academicis 1707 - RMK II 2299, and the second edition in 1765.

- Somnium philosophi repraesentans Tabulam Cebetis philosophi Platonici et Enchiridion Epicteti philosophi Stoici ... praeside reverendo patre Georgio Raicsani e Societate Jesu. Tyrnaviae, Typis Academicis [1707] - RMK II 2300 and RMK II 2300a.

- Bellum contra hostes capitales animae. Tyrnaviae, Typis Academicis 1718, 1720, 1725, 1807.

- Conclusiones scientiae practicae, quas tam in rebus prosperis, quam adversis recta dictat ratio. Tyrnaviae, Typ. Gall. 1718.

In this study I will present his dissertation entitled Laurus tuta a fulmine, as this work has so far been omitted during the researches carried out in the field of the history of literature or of the religious commune.

elöadásai. [Varietas gentium, communis latinitas. Papers of the 13th International Congress of the IANLS presented in Szeged]. Szeged 2008, 59-68; BíRÓ, Cs.: La Fortuna dei gesuiti di Tirnavia. Le edizioni del libro De remediis utriusque Fortunae a Tirnavia. In FebBo, M. - SAlWA, P. (pod. red. - a cura di): Petrarca a jedność kultury europejskiej - Petrarca e l'unità della cultura europea. Materiały międzynarodowego zjazdu - Atti del Convegno Internazionale Warszawa, 27-29 V 2004. Warszawa 2005, 477-484.

${ }^{2}$ TAMÁs Zs.: Rajcsányi György. In Magyar Müvelödéstörténeti Lexikon IX [Encyclopaedia of Hungarian Cultural History]. Budapest 2009, 352-353; SZINNYEI J.: Raicsani György. In SZINNYEI J. (ed.): Magyar irók élete és munkái XI [The Life and Work of Hungarian Authors]. Budapest 1906, 434435.

${ }^{3}$ SZABÓ K.: Régi Magyar Könyvtár II-dik kötet. Az 1473-tól 1711-ig megjelent nem magyar nyelvü hazai nyomtatványok könyvészeti kézikönyve [Old Hungarian library. Vol. II: Bibliographical Handbook of Foreign-Language Books printed in Hungary from 1473 to 1711]. Budapest 1885. In what follows: RMK II.

Acta Ant. Hung. 54, 2014 
The new stoical trend, emerging all around Europe, mainly thanks to the work of Justus Lipsius, brought back the thesis of stoical ethics. ${ }^{4}$ In Hungary the period after 1590 is considered as that of the new stoical philosophy in various scopes of everyday life, such as literature, religion and politics; all in which the trend emerged in an independent manner. The popularity of stoical ideas can largely be explained by the fact that its doctrines could easily be applied and adjusted to the basic principles of life both for the different populations of the society and for the various confessional groups. ${ }^{5}$ The beginning of the 18th century, called "the Indian Summer of Hungarian Stoicism" by József Turóczi-Trostler in his study entitled "Christian Seneca", is defined by the publication of several stoical-minded works by a small group of Jesuits acting in collaboration with the University of Nagyszombat. ${ }^{6}$ The didactic prosaic work of György Rajcsányi, the Laurus tuta, was also written during this era, and was published in Nagyszombat twice: in 1707 and in 1765.

The dissertation is based on the metaphor of a laurel tree standing on a mountain: in the introduction Rajcsányi gives the portrait of a laurel tree protecting against thunder strokes. The mountain on which the tree grew is the place of Jesus' Sermon on the Mount, so it represents all the knowledge the Coelestis Philosophiae Magister had taught his pupils. The laurel tree itself equals to the will of humans to show absolute surrender towards Divine Providence. The three chapters following the introduction describe the three parts of the metaphor progressing from the bottom upwards. The first one talks about the roots of the tree, thus the basis of the belief in Divine Providence. Rajcsányi, through representing God's creatures, depicts the caring love of God.

The dogma of Divine Providence signifies the will of God with which he drives his creatures towards the aims that he set himself. ${ }^{7}$ His care, spreading out to all his creatures, is the consequence of his sovereignty and has two main aspects: keeping and governing the creatures; the aim is the glory of God. Providence is the act by which God would interfere directly or indirectly in the life of his creatures, which might appear in numerous different forms in practice.

${ }^{4}$ TURÓCZI-TROSTLER J.: Keresztény Seneca. Fejezetek a kései humanizmus európai és magyarországi történetéböl [Christian Seneca. Chapters from the History of Late Humanism in Hungary and Europe]. Budapest 1937, 15-18; Cf. Long, A. A.: Hellenistic Philosophy. Stoics, Epicureans, Sceptics. Berkeley and Los Angeles 1986 2 232-241; KRAYE, J.: Stoicism in the Renaissance from Petrarch to Lipsius. In Blom, H. W. -WinKEL, L. C. (ed.): Grotius and the Stoa [Grotiana, New Series Vol. 22/23]. 2001/2002, 21-46; PAPY, J.: Lipsius' (Neo-)Stoicism: Constancy between Christian faith and Stoic virtue. In BLOM-WINKEL 47-72.

${ }^{5}$ KLANICZAY T.: A magyar későreneszánsz problémái (Stoicizmus és manierizmus) [Problems of the Late Renaissance in Hungary (Stoicism and Mannerism)]. In IDEM: Reneszánsz és barokk [Renaissance and Baroque]. Budapest 1961, 303-339; ÁCS P.: A késő reneszánsz meglazult pillérei: a sztoicizmus és a manierizmus az irodalomban [The Loosened Columns of the Late Renaissance: Stoicism and Mannerism in Literature]. In MiKÓ Á. - VERÖ M. (ed.): Mátyás király öröksége. Késö reneszánsz müvészet Magyarországon (16-17. század). Kiállitás a Magyar Nemzeti Galériában 2008. március 28-2008. július 27. [The Inheritance of King Matthias. The Art of the Late Renaissance in Hungary (16-17th century). Exhibition at the Hungarian National Gallery, 28. 03. 2008 - 27. 07. 2008] Budapest 2008, 36-50.

${ }^{6}$ TURÓCZI-TROSTLER (n. 4) 22-33.

${ }^{7}$ DeusER, H.: Vorsehung I. In Theologische Realenzyklopädie, Bd. XXXV. Hrsg. von G. MÜLLER. Berlin - New York 2003, 302-323. 
The belief in Divine Providence contradicts all concepts related to "chance", "luck", "fate" etc. Rajcsányi states that it should be considered as profanity if someone used these expressions. Christians all know that no events happen by chance, everything follows God's will and only sin takes place without God's agreement but with his permission. Events that we consider calamities do not come to us as harms but should be considered as events by which God tries to help us. Consequently, humans should choose a way of life in which all of their will harmonizes with the will of God.

The second chapter of the Laurus tuta discusses the greenery of the tree representing the concepts of the wisdom and omnipotence of God through referring to numerous examples from the Bible. Rajcsányi puts a lot of emphasis on this chapter, as without interpreting these characteristics of God he would not be able to elucidate the principle of Providence. The wisdom of God is the infallible knowledge he uses to govern the Universe he had created and that from eternity. With this knowledge in hand God knows exactly what serves the benefit and salvation of a person. Being omnipotent, he can achieve everything he thinks would be useful and benign. All his acts come from his kindness and love.

The third chapter talks about the lightnings appearing close to the tree that cannot harm it - the representations of calamities afflicting humans. We can distinguish three types of them: the dry lightning (fulmina sicca) that represents the lack of natural aptness such as the lack of wealth or function. These things often interpreted as negative are present in our lives because of the will of God and with the aim to benefit us. To explicate the theme, Rajcsányi uses c. 17 of the Handbook of Epictetus: the wellknown metaphor of life being a theatre explains that our life is a play, people are actors and God is the stage director. Going further following the idea of Epictetus, Rajcsányi forewarns people that the biggest glory does not go to the person who had the noblest role but to the person who plays his character the most realistic way. Thus we have to accept the role the director gave us and play it without rebel. It is God's task to choose our role, ours is simply to accomplish it.

The second type of adversity is the lightning appearing with rain (fulmina humi$d a$ ) that represents the diseases attacking humans. We should not rebel against these diseases as God knows exactly what is beneficial to us. When he believes that good health would be beneficial, he will arrange our life accordingly using his omnipotence. We should strictly avoid all methods of cure related to superstition and blasphemy. In this part of his manuscript he returns to the theatre-metaphor of Epictetus: if the director had given you the role of an ill person, you should play it well so that spectators, including angels and other beings in heaven, will enjoy it. They especially appreciate the patience one displays when suffering from illness or pain.

Fiery lightning (fulmina ignea) represents famine, epidemics, wars, earthquakes and floods, thus all the catastrophes of nature and humanity. The idea of Divine Providence applies to the history of humanity just as it does to all individual beings.

Where did the idea of Rajcsányi with the metaphor of the laurel tree come from? Plinius the Elder describes the various tree species in Book 15 of his Naturalis 
historia that includes the description of the laurel tree in chapters $39-40 .^{8}$ The laurel tree belongs to the family of the Lauraceae, it is a small-size evergreen tree. One can distinguish two species: that of Delphi and the other one of Cyprus. The two have a different size and leaf colour. After the overall portray of the tree we find the description of its use and beliefs related to it. It is widely known that during the triumphal march generals wore a laurel wreath as a sign of immortality gained by the victory. Plinius also mentioned that houses decorated with laurel were avoided by lightnings. Suetonius also emphasized the protecting character of the tree in the biography of Tiberius:

[Tiberius] ... circa deos et religionibus neglegentior, quippe addictus mathematicae plenusque persuasionis cuncta fato agi, tonitrua tamen praeter modum expavescebat et turbatiore caelo numquam non coronam lauream capite gestavit, quod fulmine afflari negetur id genus frondis. ${ }^{9}$

In Christian symbolism the laurel represents martyrdom and immortality. The laurel tree and the laurel wreath also appears in the representations of emblem literature: in the collection of the emblems of Johannes Camerarius published in 1590, a laurel tree planted on the top of a mountain with black, zigzagging lightning around serves as the symbol of pure and intact chastity. ${ }^{10}$ Although none of the published works of Rajcsányi include illustrations, in the preface of his work he presents the laurel tree on the mountain in such a picturesque way that we may hypothesize that his idea serving as the basis of his writing came from a picture or an emblem.

In this dissertation, György Rajcsányi attempted to attune the principles of stoicism, the Christian tenets and the problems of practical life using the dialogue of Seneca dealing with providence (De providentia) and the Handbook of Epictetus. Beside these resources he used the writings of the Fathers of the Church although these are not present throughout the whole dissertation as the stoic sources are, but illustrate or underline one or another statement. ${ }^{11}$ He tries to resolve the contradiction between the tenet of providence and everyday problems found in the work of Seneca: if Divine Providence exists, how is it possible that trustworthy people sometimes suffer more than dishonest ones. Seneca believes that this happens because God teaches his people through calamities, so that those he appreciates more can learn to display their virtues. From his work De providentia only six chapters have survived and the end of the work is lost. The first chapter shows, through the discussion about natural phenomena, that nothing in life happens by chance. After this part Seneca writes about the fact that good people resemble gods and remain worthy whether something good or bad hap-

\footnotetext{
${ }^{8}$ Caius Plinius Secundus, Naturalis Historia. Libri XXXVII. Ed. K. F. T. MAYHOFF. Lipsiae, Teubner 1892-1909.

${ }^{9}$ Suetonius, Vita Tib. 69. Cf. Lives of the Caesars. Vol. I: Julius. Augustus. Tiberius. Gaius. Caligula Suetonius. Ed. by J. C. RoLfE [LCL 31]. The Harvard University Press 1914, 392.

${ }^{10}$ Henkel, A. - SCHÖNE, A.: Emblemata. Handbuch zur Sinnbildkunst des XVI. und XVII. Jahrhunderts. Stuttgart 1967, 204.

${ }^{11}$ Rajcsányi quotes for example: Augustinus, De civitate Dei, Enarratio in Psalmos; Boethius, De consolatione philosophiae; Dionysius Areopagites, De divinis nominibus.
} 
pens to them. Through the disasters that are to be interpreted as trials, their fortitude comes to light. For Seneca, the example of the stoic sage was Marcus Porcius Cato Minor, also called Cato Uticensis; Seneca depicts the proper attitude a wise man has towards life through the description of Cato's way of life.

György Rajcsányi professedly follows the philosophical writing of Seneca, he even refers to the first chapter of the De providentia where it talks about the natural phenomena created by God. He also cites another work of Seneca, the De vita beata, and the command found in this philosophical writing, namely Deum sequere!, appears several times through the dissertation. The other stoic source he uses is the Handbook of Epictetus that he cites several times, too. Epictetus lived between 50-138 AC, he came to Rome as a slave. After getting liberated, he founded his broadly appreciated school in Nicopolis, in Epirus. In his diatribes he discussed the questions of practical ethics. Several of his thoughts similar to those found in the De providentia were also used by Rajcsányi. Among the reprints of Nagyszombat connected to Rajcsányi listed at the beginning of the study we find the Somnium philosophi repraesentans Tabulam Cebetis... et Enchiridion Epicteti. The second half of this work contains the Handbook of Epictetus in Latin. This print published by Rajcsányi provides evidence how important the tenets of stoicism were for the Jesuits of Nagyszombat, and how well Rajcsányi knew them.

We can summarize the stoic bases of Rajcsányi's work of by the following statements: God, who created the world, is governing it and nothing happens by chance. Things that we, humans, consider as evil, as troubles or calamities are in fact beneficial to us. They all happen to us thanks to the will and wisdom of God. Their aim is to shape us and to make us repent.

Since everything in the world follows God's will and happens with his permission, the best choice for us is to accommodate our will to his. This thought parallels with c. 13 of the Handbook of Epictetus that Rajcsányi cites. ${ }^{12}$ We should not ask for events following our own will. Instead, we should accommodate to what happens to us. To control our own will, Rajcsányi suggests three possibilities: firstly, we should not oppose the will of God, as doing that is useless and silly. Secondly, we should never consider any incident as the result of hazard or luck. Thirdly, we should avoid explaining any event by human negligence or malignity as everything derives from God except for sin.

Rajcsányi reasons long about the relativity of things: we cannot judge our own situation fairly, as anything beneficial for one is deteriorative for another one. For a sailor wind is important, still most people prefer calm weather. Farmers like rain while wayfarers prefer no clouds. Merchants like bad, poor people prefer copious harvest. Mercenaries want war while citizens wish for peace. Only God, who, thanks to his wisdom, arranged everything in the Universe in the most proper way possible, is able to control everything.

\footnotetext{
${ }^{12}$ Ex Epicteto monuimus, ut, ne postules ea, quae fiunt, arbitratu tuo fieri, sed si sapis, ita fieri quaeque velis, ut fiunt: probe sciens, omnia regi a sapientissimo. Laurus tuta II 1. 69.
} 
Now let us turn to how Rajcsányi makes the doctrines of stoicism acceptable for Jesuit spirituality, with what thoughts he Christianizes them in his dissertation. Among Jesuit spiritual works that of György Rajcsányi is not the only one incorporating stoic mentality into the discussion about Christian precepts. When presenting the Laurus tuta, one cannot avoid mentioning the spiritual work of the Jesuit Alphons Antonio de Sarasa (1618-1667), working in Antwerp and Brussels. His writing, the Ars semper gaudendi, ${ }^{13}$ was highly popular and has been published several times including one edition in Nagyszombat in $1676 .{ }^{14}$

Sarasa's work is lengthier and includes more theological knowledge than the Laurus tuta, and its structure is also different. It is divided into three large parts: the first part shows continuous happiness (gaudium perpetuum) that comes from the faith in Divine Providence. The second part disproves the doubts about Divine Providence, finally the third part deals with the faith in Divine Providence in practice. The comparative analysis of the quotations of both works supports that Rajcsányi produced his work with use of Ars semper gaudendi.

Although the Laurus tuta displays numerous differences compared to the Ars semper gaudendi both in the order of its contents and in the order of the priority of its topics, it is evident that Rajcsányi knew the book very well and used several quotes and passages from it without referring to Sarasa. While Sarasa stressed the theology of history, meaning the actions of God through history and the historical events taking place in the life of different nations more, Rajcsányi places greater emphasis on the role of Providence in the lives of individual people. His examples, illustrations, the Christian and stoic sources, especially the quotes coming from Epictetus can also be found in Sarasa's work in the very same form.

There are several examples of textual correspondence in the Laurus tuta and the Ars semper gaudendi:

\section{Laurus tuta}

Verum apage cum his, non Philosophorum, sed Epicuraeorum (quorum Deus venter est) non philosophationibus, sed delirationibus. [...] An enim, quaeso, quisquam Artifex, instrumenta artis suae, ut sint exacta, curat, ad opus tamen ipsum, cui instrumenta huiusmodi adhibentur, nihil attendit? Horologium, verbi causa, ut horae designentur, conficit Artifex, rotas summa accuratione distribuit, polit, excavat, tympana,
Ars semper gaudendi

Ita nempe Epicuraei loquuntur, quorum Deus venter est [...] An vero quisquam artifex instrumenta adhibentur, non attendit? Horologium, ut horae designentur, conficit Artifex, rotas summa accuratione distribuit, polit, excavat, tympana, conchleasque rite inserit, campanum aes super imponit, appendit pondera; horae autem ut malleo aut indice designentur, quid vero non agit?

\footnotetext{
${ }^{13}$ First edition: Ars semper gaudendi demonstrata ex sola consideratione divinae providentiae et per adventuales conciones exposita ab Alfonso Antonio de Sarasa Societatis Iesu. Antverpiae, apud Iacobum Meursium 1664.

${ }^{14}$ Ars semper gaudendi, ad veram animi quietem, ex divinae providentiae consideratione comparandam ... Tyrnaviae, Typis Academicis, per Matthaeum Rietmiller 1676. - RMK II 1385.
} 
conchleasque rite inserit, aes campanum superimponit, appendit pondera; horae interea, ut malleo, aut indice designentur, non agit? Aut si horis, utcunque invigilet, certe quadrantibus non attendit? Minutis vero multo minus? Nimis enim haec quidem exilia sunt, quam ut iis pro curandis se se impendat tantus Artifex. At, dic, obsecro, nonne, ut horae indicentur, tota constructa est machina? Quomodo ergo curat machinam, qui horas negligit? Quomodo horis attendit, cui minuta, quae horas constituunt, non sunt in pretio? Haec si in homine artifice essent perridicula, Deo artifice sunt prorsus indigna. Ethnicus certe Philosophus (quo Ethnici erubescant Philosophastri) commentator Epicteti, de Deo verbis expressis, ait: Neque vero tanquam viles res contemnit, quas condere non est dedignatus, sic, nullo modo fieri potest, quin Deus consulat rebus a se conditis. (p. 11-13)

Quapropter illud hic animo repete, quod supra, ex Epicteto monuimus, ut, ne postules ea, quae fiunt, arbitratu tuo fieri, sed si sapis, ita fieri quaeque velis, ut fiunt. (p. 69)

Nobis optime consulimus, si alte et eximie de Deo sentiamus: (Religionis, quippe erga Deum immortalem praecipuum illud est, rectas de eo habere opiniones: ait Epictetus.) (p. 65)

De hac vitae humanae comoedia sapienter admodum quemlibet monet Epictetus: Actorem, inquit, te esse memento fabulae talis, qualis Magistro probata fuerit: si brevis, brevis, si longa, longae, si mendicum te agere voluerit, fac eam quoque personam ingeniose repraesentes. Ita si claudum, si principem, si plebeium. Hoc enim tuиm est, datam personam bene effingere, eam eligere, alterius. (p. 100)
Aut, si horis utcunque invigilet, certe quadrantibus non attendit, minutis vero multo minus? Nimis enim haec quidem exilia sunt, quam ut iis procurandis sese impendat tantus artifex. Dic sodes, nonne ut horae indicentur, tota constructa est machina? Qui curet machinam, qui horas negligit? Qui horis attendat, cui minuta, quae horas constituent, non sunt in pretio? Haec si in homine artifice sunt perridicula, in Deo universi opifice, certe sunt prorsus indigna. Ethnicis Epicuraeis Ethnicum, sed aequiorem rerum aestimatorem Simplicium Epicteti c. 38. commentatorem oppono, post multa, ait is: Neque vero tanquam viles res contemnit, quas condere non est dedignatus, sic, nullo modo fieri potest, quin Deus consulat rebus a se conditis. (p. 22-23)

Illud Epicteti recole in Enchiridio, c. 12. ne postules ea, quae fiunt, arbitratu

tuo fieri: sed si sapis, ita fieri quaecunque velis, ut fiunt. (p. 9)

Tantum magna de eius Providentia habenda est opinio, uti Ethnicus Epictetus Enchir. c. 38. vidit, dum scripsit: Religionis erga Deum immortalem, praecipuum illud est, rectas de eo habere opiniones. (p. 14)

Ita praeclare admonet Epictetus in Enchirid. c. 23. Actorem esse fabulae talis, qualis Magistro probate fuerit, te memento. Si brevis, brevis, si longa, longae, si mendicum te agere voluit, fac eam personam ingeniose quoque repraesentes. Ita si claudum, si principem, si plebeium. Hoc enim tuum est, datam personam bene effingere, eam autem eligere, alterius. (p. 95) 
Rajcsányi uses the theory of Divine Providence in a similar way as stoicism did, with one limitation; everything originates from God except for sin. Sin is the result of turning away from God, thus it cannot originate from him, God simply allows sin come to our life and lets us decide if we commit it or not. According to the stoic ideas about Providence, evil comes to the lives of people to make them better, more valuable persons. The Christian approach teaches us that evil happens not only to shape our character but it may drive us to our salvation.

It is worth noting how systematically Rajcsányi adapts the principles of stoicism to the basic thoughts of the Exercitia spiritualia of Saint Ignatius of Loyola. The first principle of Ignatius states that man was created to praise, respect and serve God leading to his own soul's salvation. ${ }^{15}$ This thought is conducted further in the second doctrine saying that all creatures were created for man, to help him glamorize God and to reach his own beatitude. The third thought declares that man should use all other creatures as far as it helps him to achieve his aim, namely glamorizing God and reaching the state of salvation. The fourth and fifth fundamentals of St. Ignatius describe the concept of indifference: we should reach the state of indifference towards all other creatures. Also, we should be indifferent regarding our own life: we should not prefer health over disease, richness over poverty, respect over shame or a long life over a short one. The only thing we should wish for is to reach salvation the most efficient way possible.

The idea of indifference shows similarities to the concept of apathy in stoicism, the state of freedom from passions that is the most important criterion of being a stoic sage. Intense emotions, either positive or negative ones are far from them although they are not insensitive to those. They try to shape their own personality towards the dispassionate state. ${ }^{16}$ Their characteristics are goodwill, joy, caution, they wish the good of their fellows and they are happy about virtuous acts.

With his teaching the Jesuit teacher György Rajcsányi probably wishes to address people unknowledgeable of the specificities of Divine Providence: the style of his writing is clear and easy to understand, the structure of the sentences is comprehensible, the references are always highlighted by italic characters, usually also mentioning the original author. His use of the Latin language follows the rules of classical style and vocabulary. The structure of his work itself is also easily understandable; the

\footnotetext{
${ }^{15}$ Homo creatus est, ut laudet Deum Dominum nostrum, ei reverentiam exhibeat eique serviat, et per haec salvet animam suam; et reliqua super faciem terrae creata sunt propter hominem, et ut eum juvent in prosecutione finis, ob quem creatus est. Unde sequitur homini tantum utendum illis esse, quantum ipsum juvent ad finem suum, et tantum debere eum expedire se ab illis, quantum ipsum ad eum impediunt; quapropter necesse est facere nos indifferentes erga res creatas omnes, quantum permissum est libertati nostri liberi arbitrii et non est ei prohibitum, adeo ut non velimus ex parte nostra magis sanitatem quam infirmitatem, divitias quam paupertatem, honorem quam ignominiam, vitam longam quam brevem, et consequenter in ceteris omnibus, unice desiderando et eligendo ea, quae magis nobis conducant ad finem, ob quem creati sumus. Exercitia spiritualia S. P. Ignatii de Loyola. Versio litteralis ex autographo Hispanico notis illustrata. Auctore R. P. Joanne ROOTHAAN. Editio altera. Ratisbonae, sumptibus et typis Friderici Pustet, MCMXX, 45-48 [Bibliotheca Ascetica II].

${ }^{16}$ Cf. SANDBACH, F. H.: The Stoics. London 1975, 59-68.
} 
subtopics are marked by new chapters or paragraphs. To be more lucid, he often uses repetitions, summarizes and draws conclusions.

Although meditation about Divine Providence belongs to the science of theology, both the resources and the vocabulary of this dissertation of Rajcsányi emphasize its philosophic nature and its connection with stoicism. He repeatedly uses several expressions: he often calls Jesus Coelestis Philosophiae Magister or Coelestis Magister; the theme of his writing, the dogma of Divine Providence is called more generally Philosophia Christiana; clergymen are called Philosophiae sanctioris Magister and sacer Philosophus; while invocations to the reader usually start with o, Christiane Philosophe. We can find similar phrases in the Ars semper gaudendi, for example Divinus ille manuductor. ${ }^{17}$

Considering Rajcsányi's instructions about Divine Providence we may conclude that he explicates the tenets accepted by Jesuit spirituality, he does not try to add new thoughts to it, the emphasis is placed on the lucidity and the didactic nature of the manuscript. Just like his stoic predecessor, Epictetus, he offers a practical strategy to the reader that can be implemented to his lifestyle. As his work was probably not addressed to qualified theologians but to his students in the college to help their spiritual progression, it is a worthwhile reading for modern people, too.

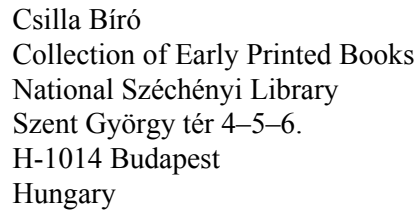

${ }^{17}$ Ars semper gaudendi 101. 